\title{
Genetic variability, heritability and genetic advance of yield and yield contributing characters of lablab bean (Lablab purpureus $\mathbf{L}$.)
}

\author{
Asaduzzaman $^{1}$, MJH Bhuiyan ${ }^{2}$, MA Hossain ${ }^{1}$, SA Raffi ${ }^{*}$ \\ ${ }^{1}$ Department of Genetics and Plant Breeding, ${ }^{2}$ Department of Biochemistry and Molecular Biology, \\ Bangladesh Agricultural University, Mymensingh 2202, Bangladesh.
}

\begin{abstract}
Studies on genetic variability, heritability and genetic advance were carried out with 14 genotypes of Lablab bean (Lablab purpureus L.) cultivated at the Agro-ecological zone9 (AEZ-9) comprising the Old Brahmaputra Floodplain Soil. Considerable amount of genotypic and phenotypic coefficient of variation was observed for all characters studied. Phenotypic variation was greater than that of the genotypic variations for all the characters. The greater portion of total phenotypic variation was due to the genotypic variation. Highest genetic and phenotypic variation were observed for green pod yield per plant (1882.68 and 2108.43, respectively) and 100green seed weight (1380.91 and 1452.07, respectively) Heritability values were higher for days to maturity (81.37) , number of raceme per plant (80.62), pod length (99.43), pod width (99.27), green pod yield per plant (89.29), dry shelling percentage (91.58), seed yield per plant (84.93) and protein content (98.11) indicating the better potentials of improving these characters for improvement of yield. Maximum genetic advance expressed as percentage of mean was recorded for green pod yield per plant (95.22).
\end{abstract}

Key words: Lablab bean, variance, genetic advance, heritability, genotypic variance, phenotypic variance

Progressive Agriculturists. All rights reserve

*Corresponding Author: raffi03@gmail.com

\section{Introduction}

Lablab bean (Lablab purpureus L.), most popularly known as 'Sheem', is an important winter vegetable in Bangladesh (NRC 2006). Its green pods as well as dried seeds are rich in protein, vitamins and minerals (Gopalan et al. 1982). Various morphotypes of Lablab bean are grown by the farmers in Bangladesh (Islam et al. 2002). These genotypes differed among themselves in respect of different morphological characters (Rahman et al. 1985) indicating existence of genetic variability. This variability is very important for any genetic improvement programme. Again, for improving the efficiency of selection in any base population, the presence of genetic variability is of prime importance. However, since most of the economically important plant characters are polygenic in nature and are highly influenced by environment, it becomes difficult to conclude whether the observed variability is heritable or is due to environmental factors. The partitioning of total variability into heritable and non-heritable components, therefore, enable us to know whether the superiority of selection is inherited by the progenies. Heritability and genetic advance stimates for different yield contributing traits help the breeder to apply appropriate breeding methodology in the crop improvement programme. Keeping the above consideration in view, the present investigation was planned to estimate the extent of genetic variability, heritability, genetic advance for different characters in 14 Lablab bean genotypes.

\section{Materials and Methods}

The experiment was conducted at the Field Laboratory, Dept. of Genetics and Plant Breeding (GPB), Bangladesh Agricultural University (BAU), Mymensingh, and carried out during the period of August 2013 to April 2014. The experimental area 
was a medium high land belonging to the Agroecological zone (AEZ-9) comprising the Old Brahmaputra Floodplain Soil (UNDP and FAO 1988). The soil was sandy loam with $\mathrm{pH}$ value of 6.5 (Alam and Newaz 2005). Fourteen climbing type of Lablab bean genotypes were used in the experiment (Table 1). Eleven of those were advanced generation lines, collected from the Field Laboratory, Department of GPB, BAU and other three were collected from neighboring villages with a status of local landraces. The materials were sown out to the field in randomized complete block design (RCBD) in three replications on $27^{\text {th }}$ August 2013. All recommended intercultural operations were done during the lifespan of the experiment. Observations for 16 different traits viz. days to $50 \%$ flowering, days to maturity, number of raceme per plant, raceme length, number of flower buds per raceme, number of nodes per raceme, pod length $(\mathrm{cm})$, pod width $(\mathrm{cm})$, number of seeds per pod, green pod yield per plant (kg), green and dry test weight (g), shelling percentage protein content (\%) and seed yield per plant (g) were recorded on randomly selected three plants in each replication were recorded from3 randomly selected competitive plants for each genotype. Analysis of variance was done for partitioning the total variation into variation due to treatments and replications according to procedure given by Panseand Sukhatme (1967). Phenotypic and genotypic variance were calculated according to the formula given by Wrickeand Weber 1986).Heritability in broad sense was calculated by the formula given by Burton and Devane (1953). The estimates of genetic advance were obtained by the formula given by Johnson et al. (1955).

Table1. List of the genotypes used in the experiment

\begin{tabular}{|l|l|}
\hline \multicolumn{1}{|c|}{ Genotypes } & Status of the genotypes \\
\hline DS-18, DS-52, DS-99, & Advanced generation \\
DS-106, DS-112, DS- & lines \\
113, DS-116, DS-164, & \\
DS-168, DS-35/A, & \\
DS-57 & \\
\hline ASHINA, & Local land races \\
KHIRSHAPATI & \\
\hline
\end{tabular}

\section{Results and Discussion}

\section{Genetic variability, heritability and genetic advance}

The genetic parameters viz. mean, range, genotypic variances, phenotypic variances, phenotypic coefficient of variation (PCV) and genotypic coefficient of variation (GCV), heritability estimates and predicted genetic advance as percent of mean for characters studied are presented in Table 2 .

In the present study, phenotypic coefficient of variation in general were higher than genotypic coefficient of variation for all the traits, but the difference was very low, indicating low environmental effect on the expression of all the traits and is suggestive of the heritable nature of the traits. These results were similar with the findings of Ganesh et al. (2005). The estimates of various genetic parameters are given in table 2.High PCV and GCV were observed for green pod yield per plant (g), dry seed yield per plant, pod length $(\mathrm{cm})$, pod width $(\mathrm{cm})$, number of raceme per plant and green test weight indicating the higher magnitude of variability for these traits and consequently more scope for their improvement through selection. Similar results were reported by Savitha (2008) and Upadhyay and Mehta (2010) for green pod yield per plant (g). PCV and GCV estimates were moderate for number of flower buds per raceme, raceme length $(\mathrm{cm})$, number of nodes per raceme, number of seeds per pod and dry test weight. This implied equal importance of additive and non additive gene action. These results were in confirmation with the findings of Golani et al. (2007) for number of primary branches per plant and days to first flowering. Low GCV and PCV estimates were recorded for days to first flowering, days to maturity, number of seeds per pod, dry shelling percentage and protein content. These results were in confirmation with the findings of Golani et al. (2007). The differences between PCV and GCV were low for days to first flowering, days to $50 \%$ flowering that these traits are less.

influenced by the environment and the effect of heritable components was high. Similar results were observed by Ganesh et al. (2005) and Rai et al. (2008). Number of flower buds per raceme, number of nodes per raceme, shelling percentage and dry seed yield per plant recorded wider difference 
between PCV and GCV values indicating dominant role played by the environment in the expression of these traits. Similar observations were also reported by Upadhyay and Mehta (2010).

All the yield and yield contributing characters showed moderate to high PCV and GCV values except days to $50 \%$ flowering, days to maturity, number of seeds per pod and protein content. Among these traits the difference between PCV and GCV values was minimum indicating that these traits are less influenced by the environment and indicates a high degree of genetic variability present in these characters and thus a greater scope for effective selection as these characters are less influenced by the environment.

Table 2. Estimation of genetic parameters for 16 characters in 14 Lablab bean genotypes

\begin{tabular}{|c|c|c|c|c|c|c|c|c|c|c|}
\hline \multirow{2}{*}{ Characters } & \multirow{2}{*}{ Mean } & \multicolumn{2}{|c|}{ Range } & \multirow[b]{2}{*}{$\delta^{2} p$} & \multirow[b]{2}{*}{$\delta^{2} \mathrm{~g}$} & \multirow[b]{2}{*}{ PCV } & \multirow[b]{2}{*}{ GCV } & \multirow{2}{*}{$\begin{array}{l}\text { Heritability } \\
\left(h^{2} b\right)\end{array}$} & \multirow[b]{2}{*}{ GA } & \multirow[b]{2}{*}{ GA\% } \\
\hline & & Min. & Max. & & & & & & & \\
\hline DFL & 90.56 & 76.83 & 105.11 & 50.07 & 35.64 & 7.81 & 6.59 & 71.17 & 10.37 & 11.46 \\
\hline$\overline{\mathrm{DM}}$ & 128.41 & 111.83 & 145.60 & 80.71 & 65.67 & 7.00 & 6.31 & 81.37 & 15.06 & 11.73 \\
\hline NRP & 25.52 & 14.0 & 28.67 & 23.76 & 19.16 & 23.56 & 21.15 & 80.62 & 8.10 & 39.13 \\
\hline $\mathrm{RL}$ & 42.88 & 34.67 & 55.67 & 43.82 & 29.90 & 15.44 & 12.75 & 68.24 & 9.31 & 21.70 \\
\hline NBR & 24.28 & 14.67 & 28.67 & 16.86 & 9.57 & 16.91 & 12.74 & 56.72 & 4.80 & 19.76 \\
\hline NNR & 10.20 & 8.17 & 12.90 & 1.88 & 1.19 & 13.43 & 10.68 & 63.25 & 1.78 & 17.50 \\
\hline$\overline{G P L}$ & 10.74 & 5.15 & 23.17 & 16.76 & 16.66 & 38.13 & 38.02 & 99.43 & 8.39 & 78.09 \\
\hline GPW & 2.035 & 1.19 & 3.40 & 0.27 & 0.27 & 25.73 & 25.63 & 99.27 & 1.07 & 52.61 \\
\hline NSP & 4.70 & 4.24 & 5.58 & 0.22 & 0.16 & 9.90 & 8.50 & 73.69 & 0.71 & 15.03 \\
\hline GPYP & 111.76 & 40.00 & 238.67 & 2108.43 & 1882.68 & 41.09 & 38.82 & 89.29 & 84.46 & 75.57 \\
\hline GTW & 78.40 & 45.67 & 175.0 & 1452.07 & 1380.94 & 48.60 & 47.40 & 95.10 & 74.65 & 95.22 \\
\hline DTW & 36.36 & 25.33 & 59.67 & 96.99 & 94.39 & 27.09 & 26.72 & 97.31 & 19.74 & 54.30 \\
\hline S\% G & 28.45 & 22.17 & 43.33 & 65.87 & 51.08 & 28.53 & 25.12 & 77.54 & 12.96 & 45.57 \\
\hline S\% D & 76.81 & 62.66 & 91.00 & 59.90 & 54.86 & 10.08 & 9.64 & 91.58 & 14.60 & 19.01 \\
\hline$\% \mathrm{P}$ & 21.85 & 16.68 & 24.88 & 5.12 & 5.03 & 10.36 & 10.26 & 98.11 & 4.57 & 20.94 \\
\hline DSYP & 19.45 & 9.67 & 32.00 & 44.76 & 38.02 & 34.39 & 31.70 & 84.93 & 11.71 & 60.18 \\
\hline
\end{tabular}

In the present study, high heritability coupled with high genetic advance as percent of mean was recorded by all the characters except for number of flower buds per raceme and number of nodes per raceme. These results indicate that these characters are under the influence of additive gene action. This results were similar with the findings of Rai et al. (2006) and Savitha (2008) for marketable pod yield per plant, Ganesh (2005) for days to 50\% flowering, pod length and plant height, Rai et al. (2006) and Savitha (2008) for number pods per plant, Bendale et al. (2004). High heritability and moderate GA as percent mean values were observed for the characters days to maturity. This indicates the influence of non additive gene action and considerable influence of environment on the expression of these traits. These traits could be exploited through manifestation of dominance and epistatic components through heterosis.

\section{Conclusion}

It can be said from these estimates of genetic variability that individual plant selection for characters viz., marketable pod yield per plant, days to maturity, number of raceme per plant, pod length $(\mathrm{cm})$, pod width $(\mathrm{cm})$, green and dry test weight, shelling percentage, protein content and dry seed yield per plant showing high values of heritability, genetic advance, GCV and PCV concomitantly, would directly effective in the progeny of Lablab bean. Hence, the breeder should adopt suitable breeding methodology to utilize both additive and non additive gene effects. 


\section{References}

Alam MM, Newaz MA (2005). Combining ability for flower and pod characters of Lablab bean, Lablab perupureus (L.).Asian Journal of Plant Sciences, 4: 603-607.

Bendale VW, Topare SS, Bhave SG, Mehta JK, Madav RR (2004). Genetic analysis of yield and yield components in lablab bean (Lablab purpureus (L.) Sweet). Orissa Journal of Horticulture, 32: 99-101

Burton GW, Devane EH (1953). Estimating heritability in tall fescue (Festucaarundinaceae) from replicated clonal material. Agronomy Journal, 45: 478481.

Ganesh BN (2005). Genetic variability and divergence studies by D2 statistics and RAPD analysis in field bean (Lablab purpureus L. Sweet). M. Sc. (Agri.) Thesis, Acharya N. G. Ranga Agril. Uni. S.V.Agri. College, Tirupati.

Golani IJ, MehtaDR, Naliyadhra R, K.and Kanzariya MV (2007). Genetic variability, correlation and path analysis for green pod yield and its characters in hyacinth bean.The Orissa Journal of Horticulture, 35(1):71-75.

Gopalan CV, Ramasastri BY, Balasubramanium, SC (1982). Nutritive values of Indian food. National Institute of Nutrition, ICMR,Hydrabad.p.75.

Islam, T, Haque MN, Rahman, MM (2002). Catalogue on hyacinth beangermplasm. PGRC., BARI, Gazipur. p55.

Johnson HW, Robinson HF, Comstock RE (1955). Estimates of genetic and environmental variability of soybean. Agronomy Journal, 47: 314-318
NRC (National Research Council) (2006). Lablab. In: Lost crops of Africa, vol. II: vegetables. NRC, Washington DC, USA, pp 190-205

Panse VG, Sukhatme PV (1967). Statistical methods for Agricultural Workers 2 ndEdn ICAR, New Delhi.pp 361.

Rahman MS, Ahmed MS, Haque KR (1985). Study on the morphological characters of twenty local collections of country bean. Bangladesh Hort.13(1+2): 51-55.

Rai N, Asati BS, Singh AK, Yadav DS (2006). Genetic variability, character association and path coefficient study in pole type French bean. Indian Journal of Horticulture, 63(2): 188-191. $506 \mathrm{~V}$.

Rai N, Singh PK, Verma A, Lal H, Yadav DS, Rai , (2008). Multivariate characterization of Indian bean Lablab purpureus (L.) genotypes. Journal of Plant Genetic Resources 21(1) 42-45.

Savitha BN (2008). Characterization of Avare (Lablab purpureus L. Sweet) local collections for genetic variability. MS Thesis, University of Agricultural Sciences, Dharwad.

UNDP, FAO (1988). Land resources Appraisal of Bangladesh of Agriculture Development. Agro-ecological Regions of Bangladesh. Report 2 UNDP/FAO, Rome, 212-221.

Upadhyay C, Mehta N (2010). Biometrical studies in Dolichos Bean (Dolichos lablabL.) for Chattisgarh Plains. Research Journal of Agricultural Science, 1(4): 441-447.

Wricke G, Weber WE (1986). Quantitative Genetics and Selection in Plant Breeding. Walter de Gruyter\& Co. Berlin, Germany. 